\title{
CZY IFING TO ILFING? RZEKA GRANICZNA W KONTEKŚCIE TOŻSAMOŚCI KULTUROWEJ MIESZKAŃCÓW TRUSO
}

\author{
IS IFING AN ILFING? \\ A BORDER RIVER IN THE CONTEXT OF THE CULTURAL IDENTITY \\ OF TRUSO SETTLERS
}

\begin{abstract}
The trading centre in Janów Pomorski is a well-researched and documented settlement. However, no research has been conducted into the toponymy in the context of the cultural identity of Truso settlers. This article is an original reflection on the possible relations between Ilfing, a river known from Wulfstan's account, and Ifing mentioned in the Poetic Edda. Professor L. Słupecki's remark on the undeniable similarity of the two names of the rivers inspired a stimulated discussion.
\end{abstract}

Keywords: Emporium, Ifing, Ilfing, The Viking Period, river, cultural identity, Truso.

Rozpatrywanie tożsamości kulturowej jest niełatwym zadaniem dla antropologa kultury zajmującego się współczesnymi społeczeństwami. Dysponuje on jednak odpowiednim aparatem badawczym, opartym przede wszystkim na bezpośrednim kontakcie z ludźmi. Odrzucając takie czynniki, jak celowe zakłamywanie statusu społecznego, tożsamości i przynależności kulturowej przez badanych, wyniki analiz antropologicznych są stosunkowo jednoznaczne w interpretacji.

W przypadku badań archeologicznych zasadnicza różnica nie polega na analizowanym zjawisku - wszak w obu przypadkach jest to kultura - a na narzędziach badawczych. Antropolog kultury obcuje z przedmiotem badań bezpośrednio, natomiast archeolog bada kulturę poprzez jej przekaźnik, którym są przedmioty wytworzone przez dawne społeczności. Pozwalają one na próbę semantycznej interpretacji nadanego im przez ich użytkowników znaczenia. Zrozumienie niektórych znaczeń możliwe jest dzięki spojrzeniu na przedmioty z perspektywy źródeł pisa-

\footnotetext{
* Instytut Archeologii i Etnologii Polskiej Akademii Nauk, al. Solidarności 105, 00-140 Warszawa, jakub.jagodzinski@gmail.com
} 
nych i mitów. W przypadku tego przyczynkowego artykułu kluczowe znaczenie mają wyłącznie źródła pisane - relacja Wulfstana i Edda Poetycka. Analiza tych źródeł ma na celu określenie znaczenia rzeki Ilfing dla mieszkańców osady w Janowie Pomorskim. Badanie kultury materialnej w kontekście tożsamości kulturowej mieszkańców Truso powinno stanowić przedmiot osobnych rozważań.

Osada w Janowie Pomorskim jest w środowisku naukowym powszechnie utożsamiana ze znanym z przekazu Wulfstana (ryc. 1), wczesnośredniowiecznym emporium Truso (m.in. Mangelsdorf 2004, s. 54-55; Jagodziński 2010; Brather i Jagodziński 2012, tam dalsza literatura) ${ }^{1}$. Relacja anglosaskiego podróżnika stanowiła punkt wyjścia do poszukiwań Truso. Uczeni od drugiej połowy XIX w. podejmowali próby lokalizacji osady (m.in. Neumann 1854, s. 290-326; Kolberg 1878, s. 1-71). Przed II wojną światową swoje koncepcje przedstawili też niemieccy archeolodzy, m.in. Bruno Ehrlich (1937, s. 1-17) i Werener Neugebauer (1944, s. 154-161). Po wojnie poszukiwania Truso kontynuowali polscy uczeni (m.in. Żak 1961, s. 137-142; Mielczarski 1963, s. 3-36; Powierski 1971, s. 349-353; Haftka 1975, s. 246-248).

Historia poszukiwań osady Truso obejmuje wiele epizodów, teorii badawczych, mniej lub bardziej trafnych prób lokalizacji jej miejsca (Jagodziński 2010 s. 37-46; ryc. 5). Przełomowy dla ustalenia lokalizacji Truso okazał się, wprowadzony pod koniec lat 70. XX w., program AZP (Archeologiczne Zdjęcie Polski). W roku 1981, $\mathrm{W}$ ramach przygotowań do realizacji wspomnianego projektu, Marek Jagodziński dokonał odkrycia wczesnośredniowiecznej osady rzemieślniczo-handlowej w Janowie Pomorskim² (Jagodziński 1984, s. 66; Brather i Jagodziński M.F. 2012, s. 15; Jagodziński J. 2013, s. 9; ryc. 6; ryc. 7). Korelując przekaz anglosaskiego żeglarza Wulfstana z odkrytymi w trakcie badań artefaktami i ekofaktami, można było z dużym prawdopodobieństwem stwierdzić, że odkryta osada to poszukiwane od XIX w. Truso.

Osada w Janowie Pomorskim została założona nad jeziorem Drużno, na granicy Żuław i Wysoczyzny Elbląskiej, w linii prostej 15 kilometrów na południe od dzisiejszego Zalewu Wiślanego (ryc. 2). Istotną cechą z perspektywy zakresu przestrzennego było wodne połączenie z otwartym akwenem Morza Bałtyckiego poprzez rzekę Elbląg (Ilfing), Zalew Wiślany (Zalew Estyjski) i przerwę w Mierzei Wiślanej (Szukalski 1961, s. 179-198; Kondracki 1981, s. 276; Jagodziński M.F. 2010, s. 69-73).

\footnotetext{
${ }^{1}$ Obecnie nazwa wsi Janów Pomorski zmieniona została na Janów. W celu zachowania porządku, na wzór wcześniejszych opracowań, nazwa wsi, w której odkryto osadę, wykorzystana zostanie w wersji pierwotnej. W zależności od kontekstu, nazwy Truso i osada w Janowie Pomorskim stosować będę zamiennie.

2 Badania całego obszaru 17-52 przeprowadzono w 1982 r., natomiast osada Truso została odkryta podczas wyprzedzających penetracji terenowych prowadzonych przez Marka Jagodzińskiego w 1981 roku.
} 
Odkrycie to nadało szczególnego znaczenia relacji Wulfstana i bezsprzecznie potwierdziło wartość całego przekazu. Wprawdzie z relacji nie dowiadujemy się nic na temat samej osady Truso, jej mieszkańców, kultury, etnosu czy wierzeń, jednak Wulfstan określił dość dokładnie położenie emporium. Wskazał główne rzeki (Ilfing, Wisła), opisał sytuację kulturową po obu stronach Wisły - na wschód od rzeki ziemie Estów, na zachód Słowian (Jagodziński M.F. 2010, s. 12). Relacja i geograficzny opis są przekonujące, mimo pewnych nieścisłości, które wynikają ze zmian hydrograficznych opisywanego terenu względem czasów współczesnych (ryc. 3; Kasprzycka 1998, s. 45, ryc. 6).

W relacji ze swojej wyprawy do Truso Wulfstan wymienia rzekę Ilfing. Warto zauważyć, że obie nazwy przetrwały do dziś - Truso w nazwie jeziora Druzno, Ilfing w nazwie rzeki Elbląg, która wypływa z tego jeziora ${ }^{3}$. Z relacji Wulfstana wynika, że rzeka Ilfing, położona między Weonodlandem a Witlandem, znajdowała się na pograniczu terytoriów zamieszkiwanych przez różne kulturowo i etnicznie społeczności - na zachód od rzeki przez Słowian, i na wschód - przez Prusów (Estów). W świetle badań osadniczych mikroregionu Truso (ryc. 4; Jagodziński M.F. 1998, s. 159-197; tenże 2009, s. 117-192) oraz relacji Wulfstana uprawnione jest zatem stwierdzenie, że rzeka Ilfing była rzeką graniczną.

Proponowana powyżej koncepcja zakładająca graniczną funkcję rzeki nie stanowiłaby dla wczesnego średniowiecza novum. O separacyjnej roli cieków wodnych można mówić od okresu neolitu do współczesności, zarówno na płaszczyźnie wierzeniowej, jak i politycznej. W starożytnej mitologii rzeki pojawiały się w formie granic, oddzielających najczęściej ziemie żywych od zaświatów (Posern-Zieliński 2000, s. 17, 19). Na kanwie znalezisk archeologicznych i źródeł pisanych wiemy, że granice starożytnego Rzymu zatrzymały się na Renie i Dunaju. Rzeki te stanowiły granicę między Barbaricum a Imperium Romanum. Przez pewien okres wczesnego średniowiecza Łaba oddzielała ziemie Germanów i Słowian. Z kolei Noteć i dolny fragment Warty oddzielały plemiona pomorskie od państwa polskiego (Gaziński 1997, s. 63). W połowie XI w. Odra oddzielała państwo niemieckie od polskiego, stanowiąc naturalną formę fortyfikacji (Leciejewicz 2002, s. 249). Ponadto wskazać warto bałkańską Maricę, która oddzielała Greków od Traków, czy zlewiska Prypeci, Dniepru i Desny, które oddzielały ziemie Bałtów od południowo-wschodniej Słowiańszczyzny. W kontekście globalnym wymienić należy choćby azjatycki Indus, który od czasów kultury harrapańskiej rozdziela ludy pastersko-góralskie od drawidyjskich Indii, a także amerykańską Orinoko, dzielącą kultury stepowe od plemion selwy. Przykłady granicznej funkcji rzek w dziejach ludzkości są liczne. Mogą dotyczyć społeczności lokalnych, plemion, a nawet organizacji państwowych. Wskazane wyżej przykłady w żadnym stopniu nie wyczerpują tematu, w zamyśle autora mają jedynie podkreślać uniwersalizm omawianej funkcji.

\footnotetext{
${ }^{3}$ Niekiedy z uwagi na zbieżność nazw miasta Elbląg z rzeką Elbląg stosuje się nazwę Elblążka.
} 


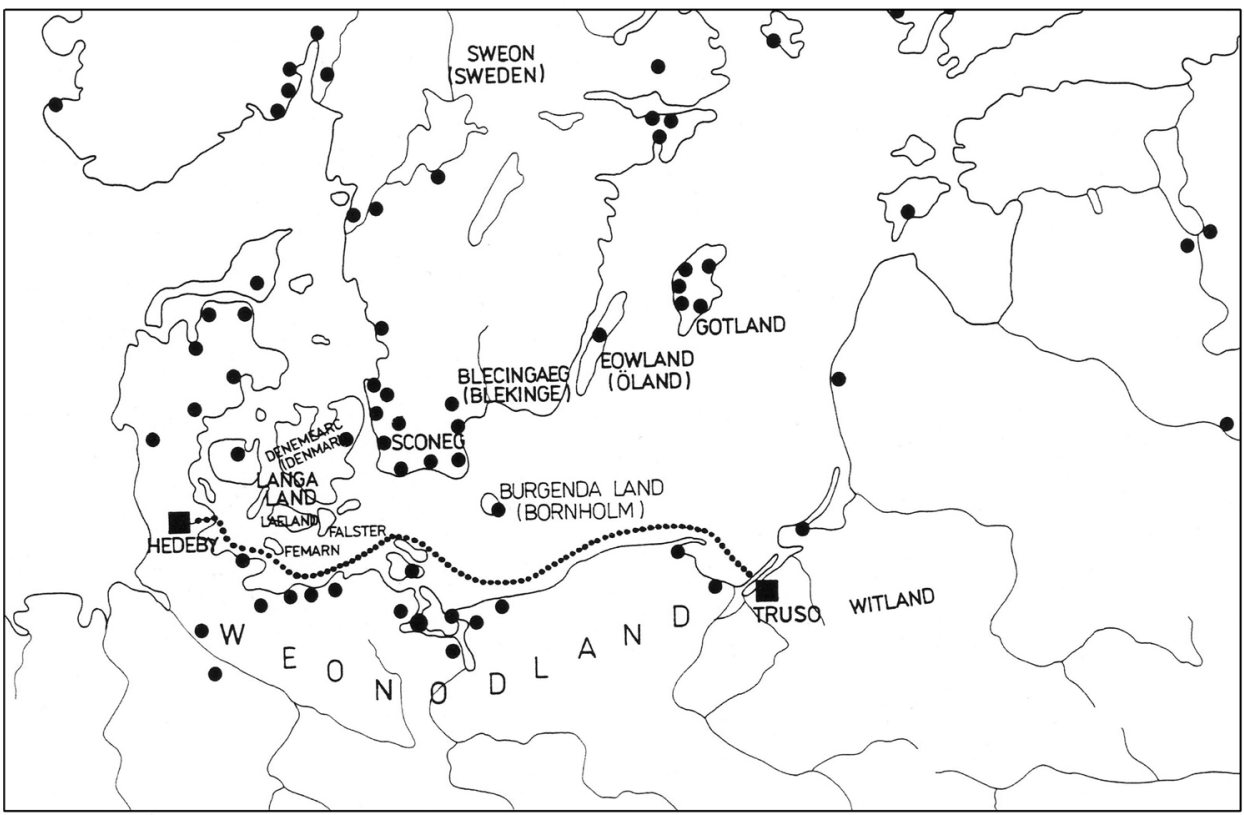

Ryc. 1. Przypuszczalna trasa podróży Wulfstana z Hedeby do Truso z nazwami ziem i portów wymienionych w sprawozdaniu. Źródło: Lund (red.) 1984, s. 40; M.F. Jagodziński 2010, s. 16 , ryc. 7

Niedawno w nawiązaniu do tej granicznej funkcji rzeki bardzo ciekawego spostrzeżenia dokonał Leszek Słupecki (2013 s. 66-67). Zauważył on, że w Eddzie Poetyckiej (Pieśń o Wafthrudnirze) Odin opowiada o rzece Ifing, która w dodatku oddziela ziemie olbrzymów od ziemi bogów4 ${ }^{4}$ L. Słupecki, wskazując na uderzające podobieństwo w nazwach oraz podobne znaczenie Ilfing oraz Ifing, sugeruje,

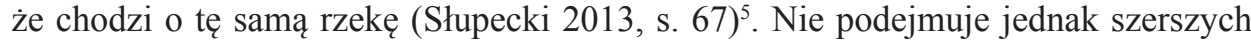
rozważań nad relacją między rzeką Ilfing, a znaną z Eddy Poetyckiej - Ifing. Uważam, że podobieństwo - zarówno nazw, jak i funkcji - być może jest nieprzypadkowe, jednak takie stwierdzenie pozostawia bez odpowiedzi nowe pytania. Najważniejsze z nich, idąc śladem rozważań L. Słupeckiego, brzmi: czy z uwagi na zbieżność nazw i funkcji należy założyć, że mityczny Odin opowiada o tej samej rzece, co Wulfstan?

4 Edda Poetycka, tłum. A. Załuska-Strömberg 1986, s. 56.

5 Leszek Słupecki przedstawił problematykę źródeł historycznych dotyczących rzeki Ilfing (2013, s. 65-69). Dla mnie stanowiło to impuls do napisania poniższych rozważań, które w żaden sposób nie zamykają dyskusji. Sygnalizują natomiast nowe pytania, na które odpowiedzi pozostają otwarte.

W tym miejscu pragnę serdecznie podziękować Profesorowi Leszkowi Słupeckiemu za cenne uwagi i pomoc w dotarciu do odpowiedniej literatury. 


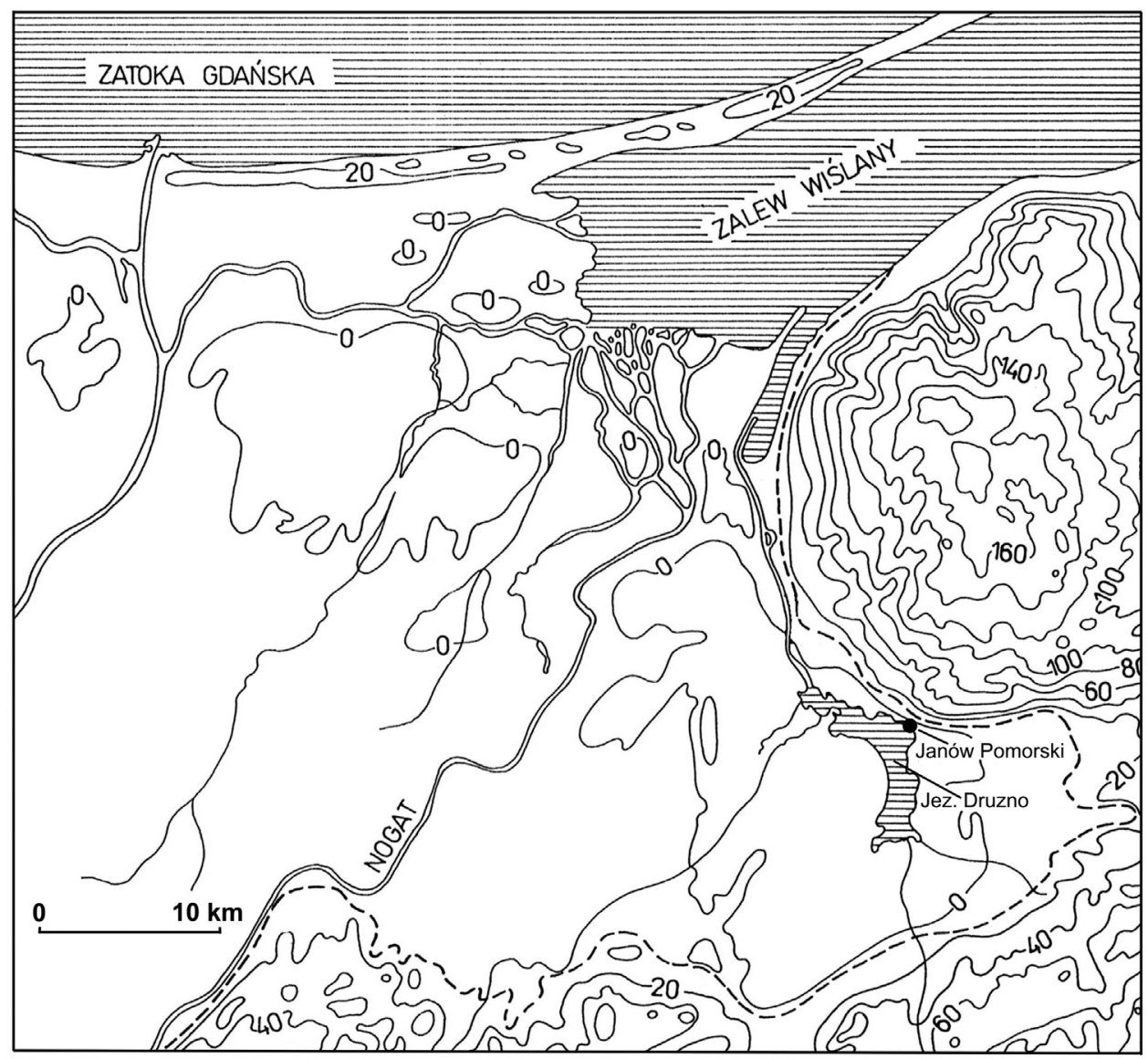

Ryc. 2. Hydrografia rejonu ujścia Wisły na tle mapy hipsometrycznej - stan dzisiejszy. Źródło: archiwum Muzeum Archeologiczno-Historycznego w Elblągu

Zakładając, że Ilfing oraz Ifing to ta sama rzeka, należy rozważyć, która nazwa była pierwsza: mitycznej rzeki, znanej z Eddy Poetyckiej, czy rzeki, o której pisał Wulfstan. Wydaje się, że oba założenia mogą być wiarygodne, jednak w obu przypadkach pojawiają się wątpliwości. Cennych wskazówek może dostarczyć chronologia: Edda Poetycka datowana jest na IX w., a początki osady w Janowie Pomorskim na koniec wieku VIII. Może to sugerować, że nazwa Ilfing najpierw powstała w odniesieniu do rzeki wypływającej z jeziora Drużno, a potem w formie Ifing trafiła do Eddy Poetyckiej. Wątpliwe jednak wydaje się, żeby islandzka saga powstała z inspiracji duńskich osadników pogranicza słowiańsko-estyjskiego. Co więcej, z ziem Słowian i Estów powstać miałyby ziemie olbrzymów i bogów.

W mojej ocenie sytuacja odwrotna - przeniesienie mitycznego obrazu na rzeczywistość zastaną na rubieży słowiańsko-bałtyjskiej - wydaje się bardziej praw- 


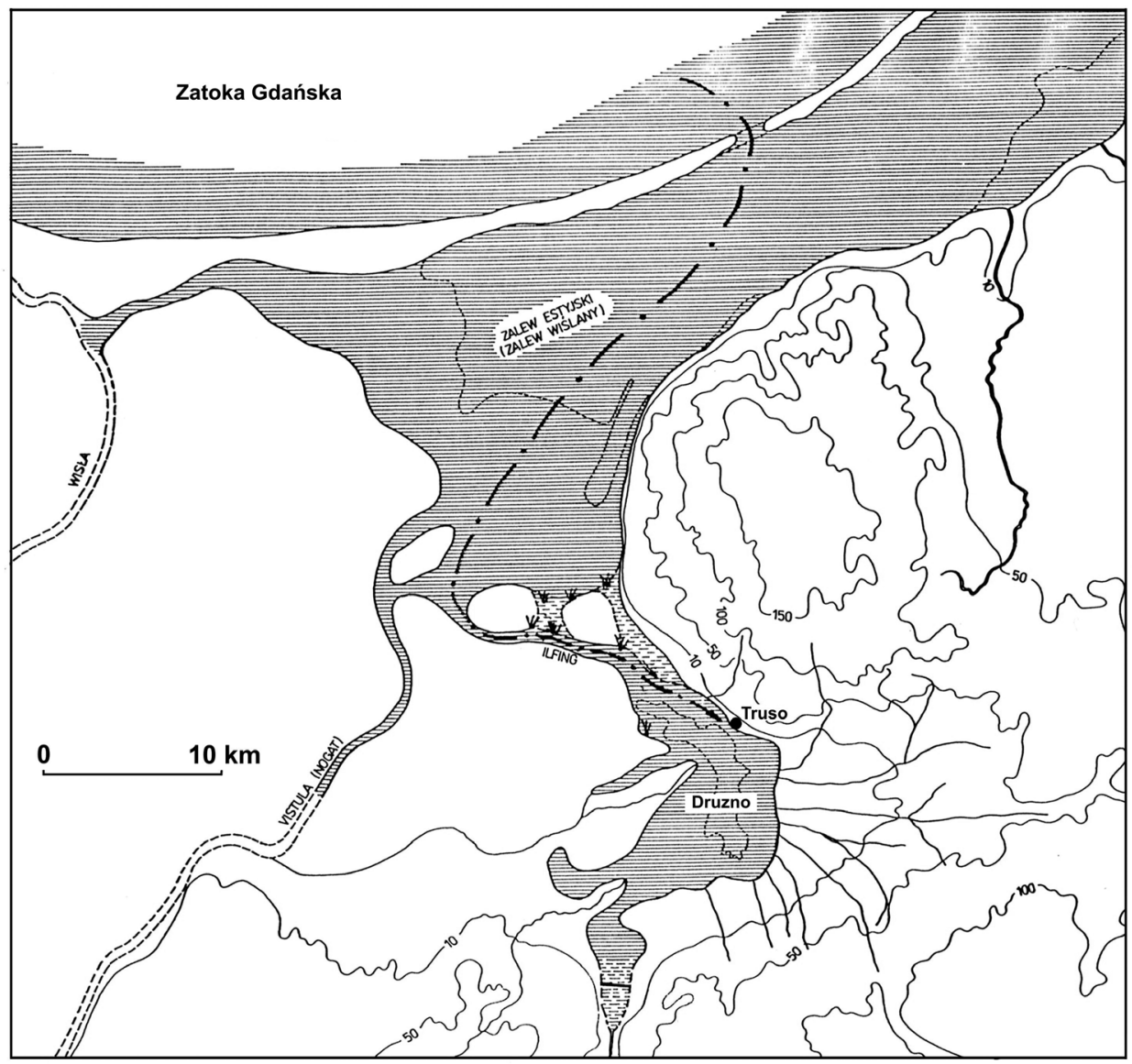

Ryc. 3. Rekonstrukcja hydrografii rejonu ujścia Wisły dla ok. 1100 lat BP. Źródło: Kasprzycka 1999, s. 171

dopodobna. Ilfing oraz Ifing nie są tą samą rzeką, natomiast podobieństwo pozostaje nieprzypadkowe. Być może nazwa Ilfing powstała jako pochodna Ifing, stanowiąc celowe nawiązanie do nazwy rzeki znanej z Eddy Poetyckiej. Metaforycznie rozumiana rzeka graniczna, oddzielająca ziemie olbrzymów i bogów, poprzez analogię funkcji zostaje przeniesiona na nową rzeczywistość osadniczą. Tłumaczyłoby to zarówno podobieństwo w nazwie, jak i graniczną funkcję rzeki. Rodzi to jednak inny problem - czy Skandynawowie mogli stanowić na tyle silną społeczność, żeby - między Słowianami a Bałtami - decydować o nazwie ważnej rzeki granicznej? Istniała ona przecież przed założeniem Truso, więc prawdopodobnie lokalne społeczności nadały jej już wcześniej jakąś nazwę. Jeżeli z kolei Skandynawowie i Prusowie nazywali tę rzekę różnie, dlaczego Wulfstan, który 


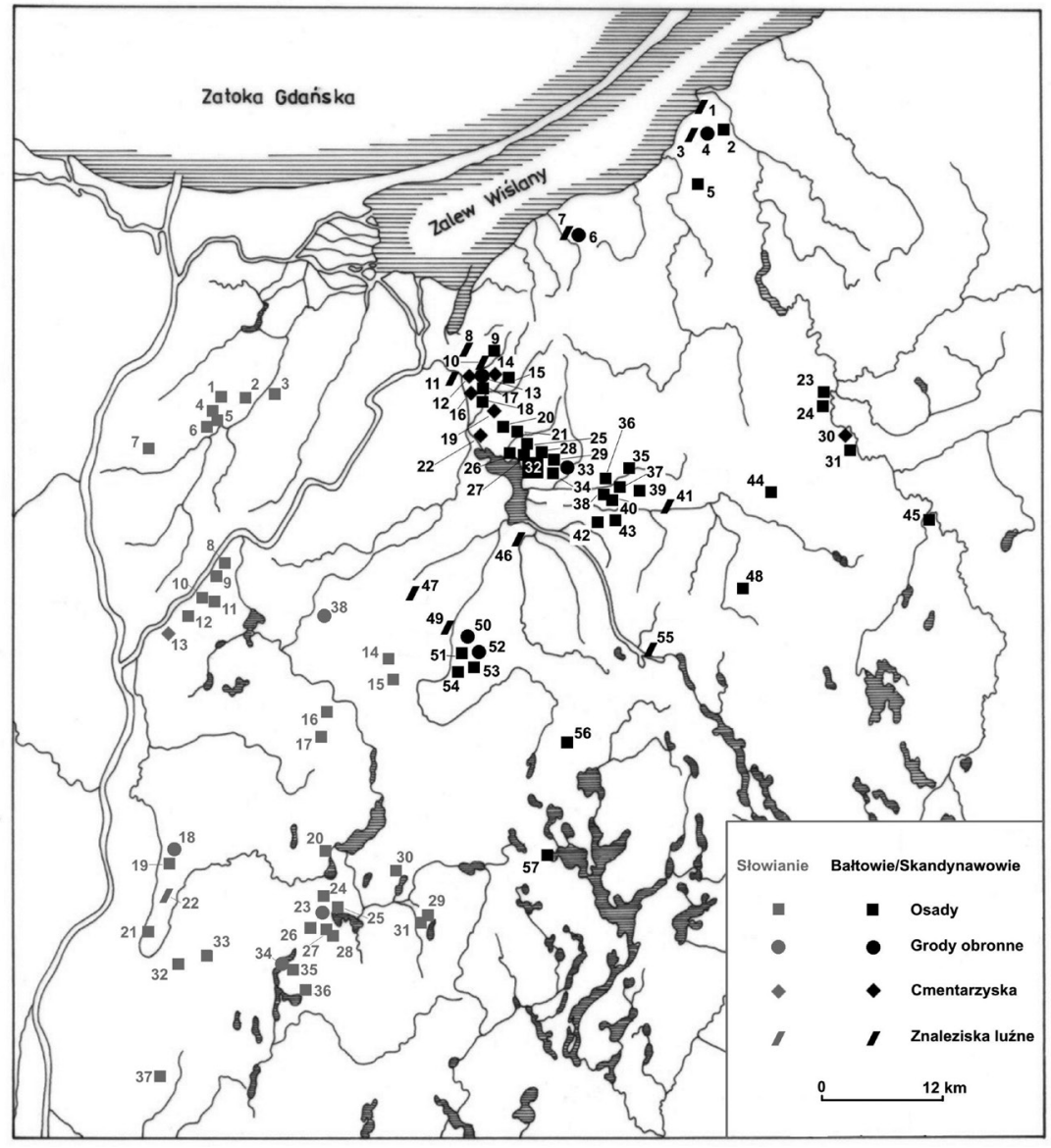

Ryc. 4. Pogranicze słowiańsko-bałtyjskie w okresie wikińskim z zaznaczonymi śladami obecności Słowian, Bałtów i Skandynawów. Opracowano na podstawie: W. Chudziak 1997; M.F. Jagodziński 1997 z uzupełnieniami autora

obcował z Estami ${ }^{6}$, odnotował jej nazwę zgodnie z nazewnictwem skandynawskim - jako Ilfing?

Warto jeszcze przytoczyć dwa, istotne z perspektywy znaczenia rzeki Ilfing, fragmenty relacji Wulfstana. Najpierw pisze on: „Wisła ta jest wielką rzeką i przez to dzieli Witland i Weonodland" (Labuda 1961, s. 85). Powyższy fragment dobitnie wskazuje na graniczną funkcję Wisły - oddziela ziemie Estów od ziem Słowian. W dalszej części relacji czytamy: „Tutaj zaś Wisła zabiera rzece Ilfing jej nazwę i spływa z tego zalewu do morza (...)". Wisła, w tym wypadku chodzi o jej wschodnie ramię ujściowe - Nogat, przejmuje (zastępuje) nazwę rzeki Ilfing. Takie

6 Świadczy o tym szeroki opis zwyczajów u Estów. 
„przejęcie” mogłoby wskazywać, że przejmuje także znaczenie, a co za tym idzie funkcję. W kontekście przedstawionego powyżej ciągu narracyjnego Wulfstana (Wisła-Ilfing-Wisłoujście) logiczne jest uznanie, że rzeka Ilfing pełniła ważną funkcję graniczną, którą dalej na północ przejęła Wisła (Wisłoujście).

Posiłkując się słownikiem etymologii staronordyckiej, termin Ifing tłumaczony jest jako „poetycka nazwa rzeki” - prawdopodobnie „gwałtowna”, „,burzliwa”, „niepohamowana”, „porywcza” (de Vries 1962, s. 283-284). W słowniku tym nie ujęto nazwy Ilfing. Natomiast określenia przypisane rzece Ifing niezbyt odpowiadają charakterowi dzisiejszej rzeki Elbląg. Obecnie jest to rzeka o spokojnym nurcie, jednak trzeba mieć na uwadze zmiany hydrograficzne na przestrzeni ponad tysiąca lat - być może wtedy Ilfing była rzeką o znacznie bardziej żywym nurcie i zapewne zmienną. W kontekście granicznej funkcji Ilfing należałoby się zastanowić, czy owa „gwałtowność” i „burzliwość” nie może być odniesieniem do charakteru granicy, którą tworzyła ta rzeka?

Do tej pory wczesnośredniowieczne rzeki analizowano przede wszystkim jako atrakcyjny szlak komunikacyjny stwarzający możliwość współpracy i łączący obce społeczności (por. Filipowiak 1992, s. 65). W powyższych rozważaniach przedstawiłem założenie, zgodnie z którym rzeka Ilfing, jako potencjalnie tożsama z mityczną rzeką Ifing, mogła pełnić także funkcję graniczną. Niezależnie od tego, czy któraś z zaproponowanych tu koncepcji jest prawdziwa, zbieżność nazw i funkcji może wskazywać na skandynawski rodowód nazwy rzeki, która wypływała z jeziora Drużno, nad którym powstała osada Truso. Jest to być może kolejna przesłanka wskazująca na tożsamość kulturową mieszkańców osady w Janowie Pomorskim.

\section{Lista stanowisk:}

\section{Baltowie/Skandynawowe}

1 - Braniewo (ujście Pasłęki do Zalewu Wiślanego), grot włóczni lub miecz wikiński, IX-XI w. 2 - Podgórze gm. Braniewo, osada pruska, IX-XI w. 3 - Sądowo, gm. Frombork, miecz wikiński, IX-XI w. 4 - Klejnowo gm. Braniewo, gród lub osada obronna, VIII-XI w. 5 - Garbina Kolonia, gm. Braniewo, osada pruska, X-XI w. 6 - Tolkmicko, gm. Braniewo, gród obronny, VIII-XI w. 7 - Tolkmicko, gm. Braniewo, ozdoby i broń wikińska, VIII-XI w. 8 - Elbląg, grot włóczni typu „E” Petersena, IX-X w. 9 - Elbląg, osada pruska, VIII-XI w. 10 - Elbląg, grot włóczni typu „E” Petersena, IX-X w. 11 - Elbląg, grot włóczni typu „B” Petersena, IX/X w. 12 - Elbląg Zawada (Pangritz-Colonie), cmentarzysko prusko-skandynawskie, IX-XI w. 13 - Bielany Wielkie (obecnie Elbląg), gród obronny, VIII-IX w. 14 - Elbląg Kamionka (Benkenstein), cmentarzysko prusko-skandynawskie, IX-XI w. 15 Elbląg, osada pruska. VIII-XI w. 16 - Elbląg Kępa Północna (Kämmerei-Sandland), cmentarzysko prusko-skandynawskie, VIII-XI w. 17 - Elbląg, osada pruska, VIII-XI w. 18 Elbląg, osada pruska, VIII-XI w. 19 - Elbląg Winnica (Weingarten), cmentarzysko prusko-skandynawskie, VIII-XI w. 20 - Elbląg Warszawskie Przedmieście (Spittelhof)), osada 
prusko-skandynawska, VIII-XI w. 21 - Gronowo Górne, gm. Elbląg, osada pruska, VIII-XI w. 22 -Elbląg Pole Nowomiejskie (Neustädterfeld), cmentarzysko prusko-skandynawskie, VIII/ IX-X w. 23 - Bardyny, gm. Wilczęta, osada pruska, VIII-XI w. 24 - Bardyny, gm. Wilczęta, osada pruska, IX-XI w. 25 - Gronowo Górne, gm. Elbląg, osada pruska, VIII-XI w. 26 Nowina, gm. Elbląg, osada pruska, VIII-X w. 27 - Nowina, gm. Elbląg, osada pruska, VIII-X w. 28 - Janów Pomorski, gm. Elbląg, osada pruska, X-XI w. 29 - Komorowo, gm. Elbląg, osada pruska, VIII-XI w. 30 - Dąbkowo, gm. Godkowo, cmentarzysko pruskie, X-XI w. 31 - Dąbkowo, gm. Godkowo, osada pruska, X-XI w. 32 - Janów Pomorski/Truso, skandynawskie emporium, VIII-XI w. (Jagodziński 2010, 2015). 33 - Myślęcin, gm. Elbląg, gród obronny, VIII/IX-X w. 34 - Myślęcin, gm. Elbląg, osada pruska, VIII/IX-X w. 35 Stegny, gm. Pasłęk, osada pruska, X-XIII w. 36 - Zielony Grąd, gm. Pasłęk, osada pruska, X-XI w. 37 - Marianka, gm. Pasłęk, osada pruska, IX w. 38 - Łączna, gm. Pasłęk, osada pruska, X-XII w. 39 - Robity, gm. Pasłęk, osada prusko-skandynawska, X-XII w. 40 - Łączna, gm. Pasłęk, osada pruska, X-XII w. 41 - Kupin, gm. Pasłęk, żelazny grot włóczni, IX-X w. 42 - Lisów, gm. Pasłęk, osada pruska, IX-XIII w. 43 - Pasłęk, gm. loco, osada pruska, X-XII w. 44 - Siedlisko, gm. Godkowo, osada pruska, IX-XII w. 45 - Stolno, gm. Miłakowo, osada pruska, VIII-XI w. 46 - Studzienki, gm. Markusy, miecz żelazny typu I Nadolskiego, IX/X- poł. X w. 47 - Jasna, gm. Dzierzgoń, miecz żelazny, X-XI w. 48 - Kronin, gm. Pasłęk, osada pruska, X-XI w. 49 - Bągart, gm. Dzierzgoń, łódź klepkowa, IX-XI w. 50 - Kwietniewo, gm. Rychliwi, gród obronny, IX-XII w. 51 - Święty Gaj, gm. Rychliwi, osada pruska, IX-X w. 52 - Kwietniewo, gm. Rychliwi, gród obronny, X-XIII w. 53 - Jankowo, gm. Rychliwi, osada pruska, IX-X w. 54 - Mokajmy, gm. Rychliwi, osada pruska, VIII-IX w. 55 - Awajki, gm. Pasłęk, miecz żelazny typu T II Petersena z inskrypcją „Ulfber(th)” na głowni, druga poł. X w. 56 - Bajdy, gm. Zalewo, osada pruska. X-XII w. 57 - Jerzwałd, gm. Susz, ufortyfikowana faktoria handlowa, liczne dirhemy i odważniki kuliste z płaszczyznami oraz kubooktaedryczne, IX-XI w.

\section{Słowianie}

1 - Lubieszewo, gm. Nowy Staw, osada słowiańska/polska, X-XI w. 2 - Mirowo, gm. Nowy Staw, osada słowiańska/polska, X-XII w. 3 - Marynowy, gm. Nowy Dwór Gdański, osada słowiańska/polska, X-XII w. 4 - Nowy Staw, gm. loco, osada słowiańska/polska, X-XI w. 5 - Nowy Staw, gm. loco, osada słowiańska/polska, X-XI w. 6 - Laski, gm. Nowy Staw, osada słowiańska/polska, X-XI w. 7 - Lichnowy, gm. loco, osada słowiańska/polska, IX-XII w. 8 - Malbork-Wielbark, gm. Malbork, osada słowiańska/polska, IX-XII w. 9 Malbork-Wielbark, gm. Malbork, osada słowiańska/polska, IX-XI w. 10 - Gościszewo, gm. Sztum, osada słowiańska/polska, IX-XII w. 11 - Gościszewo, gm. Sztum, osada słowiańska/ polska, IX-XII w. 12 - Malbork-Wielbark, gm. Malbork, osada słowiańska/polska, IX-XII w. 13 - Gościszewo, gm. Sztum, cmentarzysko ciałopalne słowiańsko-skandynawskie, X-XII w. 14 - Trankwice, gm. Sztum, osada słowiańska/polska, X-XII w. 15 - Waplewo Wielkie, gm. Stary Targ, osada słowiańska/polska, IX-X w. 16 - Nowy Targ, gm. Stary Targ, osada słowiańska/polska, X-XI w. 17 - Krastudy, gm. Mikołajki Pomorskie, osada słowiańska/ polska, VIII/IX-XIII w. 18 - Baldram, gm. Kwidzyn, gród obronny słowiański/polski, IX-XII w. 19 - Baldram, gm. Kwidzyn, osada słowiańska/polska, IX-X w. 20 - Gonty, gm. Prabuty, osada słowiańska/polska, IX-XIII w. 21 - Białki, gm. Kwidzyn, osada słowiańska/polska, X-XII w. 22 - Kwidzyn, miecz żelazny typu Y Nadolskiego, X w. 23 - Kołodzieje, gm. Prabuty, gród obronny słowiański/polski, X-XI w. 24 - Kołodzieje, gm. Prabuty, osada słowiańska/polska, X-XII w. 25 - Kołodzieje, gm. Prabuty, osada słowiańska/polska, X-XII w. 
26 - Kołodzieje, gm. Prabuty, osada słowiańska/polska, X-XII w. 27 - Kołodzieje, gm. Prabuty, osada słowiańska/polska, X-XII w. 28 - Kołodzieje, gm. Prabuty, osada słowiańska/polska, X-XII w. 29 - Bronowo, gm. Susz, osada słowiańska/polska, IX-XI w., 5 fragmentów dirhemów, 5 odważników kulistych z płaszczyznami typu B1 Steuera. 30 - Stańkowo, gm. Prabuty, osada słowiańska/polska, IX-X/XI w. 31 - Susz, gm. loco, osada słowiańska/ polska, X-XI w. 32 - Czachówko, gm. Gardeja, osada słowiańska/polska, IX-X/XI w. 33 Krzykosy, gm. Gardeja, osada słowiańska/polska, IX-X w. 34 - Klasztorek, gm. Gardeja, gród obronny słowiański/polski, IX-X w. 35 - Klasztorek, gm. Gardeja, gród/osada obronna słowiańska/polska, IX-XI w. 36 - Jaromierz, gm. Gardeja, osada słowiańska/polska, X-XI w. 37 - Gardeja, gm. loco, osada słowiańska/polska, IX-X w. 38 - Jordanki, gm. Stary Targ, gród/osada obronna słowiańska/polska, VII/VIII-XII w.

\section{CYTOWANE ŹRÓDŁA:}

Edda Poetycka, tłum. Załuska-Strömberg; 1986 Biblioteka Narodowa, Seria II; tłum. Bellows, 1936, H.A.

\section{LITERATURA}

Brather S., Jagodziński M.F. 2012, Der wikingerzeitliche Seehandelsplatz von Janów (Truso). Geophysikalische, archäopedologische und archäologische Untersuchungen 2004-2008 / Nadmorska osada handlowa z okresu Wikingów z Janowa (Truso). Badania geofizyczne, archeo-pedologiczne i archeologiczne w latach 2004-2008, „Zeitschrift für Archäologie des Mittelalters“, Beiheft 24, Bonn.

Chudziak W. 1997, Wczesnośredniowieczny szlak komunikacyjny z Kujaw do Prus - studium archeologiczne, w: „Adalbertus”, t. 2, red. W. Chudziak, red. serii P. Urbańczyk, Toruń, s. 9-31.

Ehrlich B. 1937, Der preußisch-wikingische Handelsplatz Truso. Ein Forschungsbericht, „Elbinger Jahrbuch", z. 14, cz. 1, Elbing, s. 1-17.

Filipowiak W., 1992, Z najstarszych dziejów Odry jako szlaku komunikacyjnego i handlowego, w: „Rzeki: Kultura, Cywilizacja, Historia", t. 1, red. J. Kułtuniak, s. 65-81.

Gaziński R. 1997, Z dziejów ksztaltowania się regulacji prawnych wokót europejskich rzek (od wczesnego średniowiecza do końca XVIII wieku), w: „Rzeki: Kultura, Cywilizacja, Historia”, t. 6, red. J. Kułtuniak, s. 63-84.

Haftka M. 1975, Elblag we wczesnym średniowieczu problem lokalizacji Truso, „Pomerania Antiqua”, t. 6, s. 193-280.

Jagodziński J. 2013, Wczesnośredniowieczna osada w Janowie Pomorskim jako przykład miejsca centralnego typu Seehandelsplatz w basenie Morza Battyckiego, praca licencjacka na kierunku archeologia napisana pod opieką prof. dr hab. Wojciecha Chudziaka, UMK.

Jagodziński M.F. 1997, Archeologiczne ślady osadnictwa między Wistą a Pastęka we wczesnym średniowieczu. Katalog stanowisk, „Adalbertus”, t. 3, red. serii P. Urbańczyk, Warszawa.

- 1998, Archeologiczne ślady osadnictwa między Wisła a Pasłęka we wczesnym średniowieczu. Komentarz do katalogu stanowisk, „Adalbertus”, t. 1, red. P. Urbańczyk, Warszawa, s. 159-197.

- 2009, Zagadnienie obecności Skandynawów w rejonie ujścia Wisty we wczesnym średniowieczu, „Pruthenia”, t. 4, s. 117-192.

- 2010, Truso między Weonodlandem a Witlandem / between Weonodland and Witland, Muzeum Archeologiczno-Historyczne w Elblągu.

Kasprzycka M. 1998,Mierzeja Wiślana - powstanie, rozwój, cieśniny, w: „Adalbertus”, t. 1, red. serii P. Urbańczyk, Warszawa, s. 35-47. 
- 1999, Tło paleogeograficzne osadnictwa Żuław Elbląskich w pierwszym tysiacleciu naszej ery, „Adalbertus”, t. 5, red. serii P. Urbańczyk, Warszawa.

Kolberg A. 1878, Wulfstan Seekurs für die Fahrten von Schleswig nach Truso an der Warmischen Künste von Preussen im 9 Jahrhundert, „Zeitschrift f.d. Geschichte Und Altertumskunde Ermlands”, Bd. VI, s. 1-75.

Kondracki J. 1981, Geografia fizyczna Polski, PWN Warszawa.

Labuda G. 1961, Źródła skandynawskie i anglosaskie do dziejów słowiańszczyzny, Warszawa.

Leciejewicz L. 2002, Człowiek $i$ środowisko nad Odra w czasach pra- $i$ wczesnodziejowych. Polskoniemiecki projekt badawczy, w: „Rzeki: Kultura, Cywilizacja, Historia”, t. 11, red. J. Kułtuniak, s. 237-254.

Lund N. (edit.) 1984, Two voyagers at the court of King Alfred. The ventures of Ohthere and Wulfstan together with the Description of Northern Europe from the Old English Orosius, York.

Mangelsdorf G. 2004, Kernräume und Peripherien der Besiedlung der Wikinger im Ostseegebiet, w: Siedlungsforschung, Archäologie, Geschichte, Geographie, band 22, s. 47-58.

Mielczarski S. 1963, Truso, „Rocznik Elbląski“, t. 2, s. 3-36.

Neugebauer W. 1944, Das wikingische Gräberfeld von Elbing-Neustädterfeld und die Lage Trusos, Bericht über die Kieler Tagung 1939. Forschungs- und Lehrgemeinschaft „Das Ahnenerbe“, Neumünster, s. 154-161.

Neumann F. 1854, Über die Lage von Wulfstans Truso, Wislemund und Witland-Die Namen Nehrung, Nogat, Weichsel, „Neue Provinzial - Blätter”, H. 6, s. 290-326, 385-398, 411-416.

Posern-Zieliński A. 2000, Rzeka jako element tożsamości kulturowej, w: „Rzeki: Kultura, Cywilizacja, Historia", t. 9, red. J. Kułtuniak, s. 15-40.

Powierski J. 1971, Recenzja pracy Leona Roppla, Gdzie leżało Truso? („Nautologia”, R. IV, 1969, wyd. 1970, nr 3-4, s. 13-48), „Komunikaty Mazursko-Warmińskie”, nr 2/3 (112-113), s. 349-353.

Słupecki L. 2013, Polish rivers and waters in old norse mythology, w: Scandinavian culture in medieval Poland, red. S. Moździoch, B. Stanisławski, P. Wiszewski, Wrocław, s. 65-70.

Szukalski J. 1961, Krajobraz geograficzny Elblaga, „Rocznik Elbląski”, t. 1, Elbląg, s. 179-198.

Vries J. de 1962, Altnordisches etymologisches Wörterbuch, Brill.

Żak J. 1961, Kwestia skandynawskiej faktorii w Druso, „Roczniki Historyczne”, R. 27, s. 137-142. 
